\title{
MARILUÁN DE
}

ALBERTO BLEST GANA:

\section{PANÓPTICO, UTOPÍA, ALTERIDAD*}

\section{GilberTo TRIVIÑOS***}

RESUMEN

La "singularidad esencial" de Mariluán, novela olvidada del ciclo realista de Blest Gana, se cifra en el desplazamiento de la mirada que extrae su poder del sol fecundo de la civilización por una contra-mirada iluminada por la intolerable claridad del Gran Juego en Chile: De una parte, el Otro siempre está muerto; de la otra, es indestructible.

Palabras claves: Blest Gana, Mariluán, novela, etnia, nación, utopía.

Abstract

The "essential singularity" of Mariluán, the forgotten novel of the realist cycle by Blest Gana, is encoded in the shifting of the gaze that extracts its power from the fecund sun of civilization to a counter gaze illuminated by the intolerable clarity of the Great Game in Chile: on one hand, the Other is always dead; on the other hand, he is indestructible.

Keywords: Blest Gana, Mariluán, novel, ethnicity, nation, utopia.

Recibido: 28.06.2004. Aprobado: 29.10.2004.

* Este artículo forma parte del Proyecto FONDECYT No 1.020.321: "Pemiar y castigar. La novela de aprendizaje y el poder disciplinario en la literatura hispanoamericana de los siglos XIX y XX”.

**Dr. en Literatura (USA). Profesor Titular del Departamento de Español de la Universidad de Concepción. Su libro La polilla de la guerra en el Reino de Chile tiene el Premio "Mejores Obras Literarias”, 1995, Género Ensayo, del Consejo Nacional del Libro y la Lectura. E-mail: gtrivino@udec.cl 
Mientras la historia que devoró a la muchacha

Antígona prosiga, esa historia que pide

sacrificio, Antígona seguirá delirando".

(María Zambrano, La tumba de Antígona)

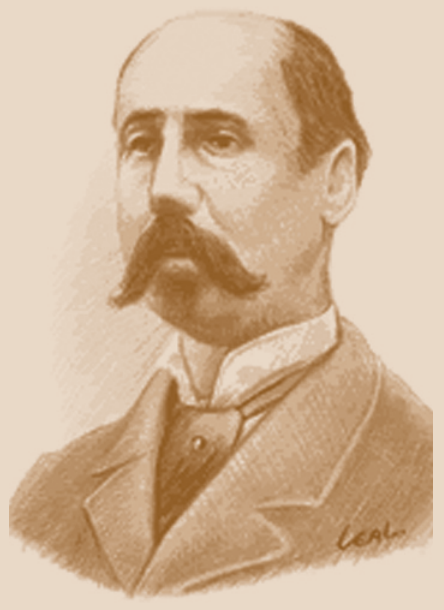

A. Blest Gana
$M$ ARILUÁN, la novela olvidada del ciclo realista de Blest Gana, reelabora de modo crítico la red de ficciones que constituye el fundamento mismo del país que se hace y se construye como nación "a partir del mapuche y contra el mapuche" (Concha 1997). Fabula provocadoramente una sociedad utópica, verdadera negación y contra-realidad de Chile en la época misma del inicio de la llamada pacificación definitiva de la Araucanía: "(Los araucanos) no podrán obtener la reparación y la justicia que merecen si no se presentan fuertes y terribles. Con el fuerte se trata y al débil se le oprime. Yo he querido salvarlos de esa opresión y que se les mire como a hermanos y no como a un pueblo enemigo del cual se pueden sacar esclavos despojándole de sus tierras" (Blest Gana 1964:232). La inactualidad de Mariluán en el siglo XIX, y aun en el XX, reside, más allá o más acá de los límites de su viaje hacia la alteridad étnica, en la ficcionalización de la resistencia de Fermín Mariluán como empresa noble y santa de un generoso descendiente de los héroes inmortalizados por la epopeya. Los chilenos, como corresponde, borramos no sólo La Araucana, las clarísimas páginas que dieron nacimiento. Olvidamos, asimismo, las obras que se inscriben en la tradición inaugurada por el poema del inventor de Chile. Mariluán y Quilapán, entre otras varias. La resistencia de los destruidos, dice Neruda, es parte concreta de mi alma. Parte también concreta de la obra de Blest Gana, el novelista chileno que deviene cronista de la rebelión del indio civilizado (re)descubridor de lo que Levinas llama el nudo mismo de la subjetividad humana a punto de erigirse en un supremo principio ético -el único incontestable- y de gobernar las esperanzas de grandes agrupaciones humanas: el sufrimiento por el sufrimiento inútil de otro hombre, el justo sufrimiento por el sufrimiento injustificable de los demás (1993:11: "Soy araucano, y no puedo mirar indiferente lo que sufren los araucanos" (Blest Gana 1964:232).

El interés académico de los historiadores y críticos literarios por esta "crónica contemporánea" del autor de Martín Rivas data literalmente de las últimas décadas, particularmente después de la publicación del artículo de significativo título de John Ballard: "Mariluán: la novela olvidada del ciclo nacional de Alberto Best Gana” (1981). Sus análisis e interpretaciones, que se separan de modo radical de la opinión negativa de Raúl Silva Castro sobre la obra cuyo autor "cedió al deseo de acumular efectos trágicos y sangrientos para producir en el lector impresiones de horror, hasta el punto de que no se divisa la razón de muchas de estas peripecias que nada tienen que ver 
con el desembarazado curso de la fábula" (1941:413), coinciden en las siguientes cuestiones fundamentales para la lectura de Mariluán como texto que reinventa de otro modo las relaciones entre araucanos y chilenos en el territorio que "no es un país de indios":

1. Mariluán es una novela contradictoria, porque junto con sugerir que "los indios son incivilizables y casi inferiores, rescata los valores positivos de esa sociedad y los derechos que les asisten para luchar por sus tierras (...) Lo interesante y novedoso, en todo caso, es "el hecho de que se trata de una obra aparecida en 1862, cuando El Mercurio de Valparaíso y El Ferrocarril de Santiago estaban en plena campaña destinada a desprestigiar a los mapuche y a crear una sensación de inseguridad, que ponía en peligro al país" (Pinto 2001:110-111).

2. “(Blest Gana, pese a ser un liberal) no puede escapar a los prejuicios y estereotipos que se van consolidando paulatinamente en la sociedad chilena del siglo XIX. Considera como valiosos: la energía indómita, el amor a la libertad y a la tierra y su orgullo de raza; pero también consigna rasgos negativos tales como 'espíritu suspicaz que dirige las acciones de las razas salvajes', desarrollo del instinto de rapiña en grado superlativo, el fatalismo y la superstición. Este enfoque dual del mapuche se percibirá en toda la novela. Debemos reconocer que Blest Gana concibe un camino que no implica necesariamente el exterminio físico del mapuche, sino que simplemente su asimilación al modelo de sociedad que se estaba desarrollando en el país, para lo cual la ocupación de las tierras al sur del Bío-Bío se presenta como una necesidad" (Antillanca y Loncón 1997:93-94).

3. Blest Gana se integra, después de su regreso a Chile desde Francia, a un grupo de jóvenes que retornan del exilio por su participación en la revolución de 1851, o que viajaron por Estados Unidos y Europa en aquellos mismos años. En "este ambiente (...) se enteró de la existencia de Mariluán. Seguramente de él le habló su tío, el coronel José Francisco Gana López, director de la Escuela Militar al tiempo que volvía de Francia, y al calor de los debates que se produjeron sobre la 'cuestión de Arauco', en las tertulias de los jóvenes liberales de El Ferrocarril, tramó su novela" (Pinto 2001:113).

4. "El conflicto de Mariluán es, al fin de cuentas, conflicto típico de la gran novela realista, el choque entre la poesía y la verdad. Sus ilusiones chocan con y se deshacen ante la dureza de lo real. Sus dos amores, el amor para con Rosa y el amor para con los araucanos devienen así amores imposibles dadas las condiciones de una sociedad en la que las diferencias de todo orden, sociales, culturales, económicas, impiden cualquier síntesis"(Ballard 1983:82).

5. Mariluán, especie de mestizo Alejo, según Silva Castro, "surge, en esta novela -e hipotéticamente en la historia- para reparar una radical escisión social, a la manera de un sujeto constructor y conciliador de mundos 
antitéticos, llamado por el destino a ser portador ilusionado y solitario de un discurso ideal de verdad y de justicia, cuyo proyecto se verá destruido por la cruda realidad social"(Barraza 2002:196).

6. La representación narrativa de los araucanos en Mariluán permanece dentro de los límites de la antinomia civilización-barbarie. El indígena 'bueno' suele tener las marcas explícitas de una occidentalización discursiva (Foresti et alii, II, 2001:213): "De acuerdo a esta percepción de los personajes, (el autor) les asignará distintos papeles en la trama de su novela: al más civilizado, el carácter de redentor; al semicivilizado, el de apego a la labor de Mariluán, obediente, leal; en tanto al salvaje: la crueldad, la traición. No puede haber un mensaje más claro de lo que se persigue como ideal, la adscripción al héroe civilizado" (Antillanca y Loncón 1997:93).

7. "El rebelde desaparece de la memoria de quien mejor pudiera retenerlo contra el olvido: El recurso al pathos folletinesco-sentimental del novelista hace que Rosa Tudela pierda la razón cuando -como bárbara venganzael asesino de Mariluán exhibe su cabeza ante su ventana, como a la manera de epílogo, escribe Juan Valero a un amigo (242.245). Lo impensado es que, con esta tachadura, la novela ha terminado por silenciar, también, su propia existencia frente a la serie narrativa del autor, siendo indudable el lugar que le ha correspondido como texto representativo del discurso de la conquista en el siglo XIX" (Barraza 2002:201).

8. "Ercilla hispanizó retóricamente a sus personajes, pero éstos no transaron su identidad de pueblo. Blest Gana rescata algo de la épica de Ercilla desde la perspectiva romántica para construir un héroe indígena y le insufla un espíritu occidental. La atracción hacia el mundo indígena en la elite intelectual se debe y pasa por La Araucana, obra que proyecta una presencia insoslayable. El aprecio hacia el otro funciona a nivel de imágenes. Pero cuando el tema se instala en la realidad concreta surgen las dificultades, pues se produce el choque con la escandalosa diferencia. De ahí las ambigüedades estéticas que se corresponden con la ambigüedad más que nada moral frente al tema de la relación entre el estado chileno y el pueblo mapuche" (Troncoso 2003:89).

9. "Romanticismo y realismo son las formas que Blest Gana utiliza para ficcionalizar la relación conflictiva de la sociedad chilena con el pueblo mapuche, pero también para proyectar sus propios conflictos: el pueblo araucano es estimable por su pasado heroico, pero su salvajismo es una condición difícil, si no imposible, de cambiar; ¿valdría la pena invertir tanto esfuerzo en un proyecto civilizador con tan inciertos resultados?, ¿ iconstituye la integración de los araucanos un factor esencial para afianzar el Estadonación? Todos estos planteamientos y preguntas están implícitos en la novela" (Troncoso 2003:90). 
Mariluán es una novela contradictoria, con ambigüedades estéticas y morales. Aquí parece estar el mayor consenso de los estudiosos de esta "tradición moderna”. Es necesario con todo leer con mayor detención el texto así definido, sobre todo para intentar precisar más rigurosamente su especificidad dentro de la historia de los textos literarios que reinventan de otro modo las relaciones entre los araucanos y los chilenos eternamente separados. Esa singularidad reside, sin duda, en las llamadas ambigüedades, pero el excesivo énfasis puesto en ellas tiende a borrar, cuando no a ocultar, la verdad novelesca de Mariluán cifrada en el germen utópico de la rebelión del protagonista. Silva Castro llama despectivamente quimera a este germen irreductible a cualesquiera de las mentiras románticas del texto. Hoy, cuando sabemos que el carácter esencial de la literatura es tratar lo todavía no manifestado como existente (Bloch), que la literatura es en última instancia una forma privada de la utopía (Piglia), podemos afirmar que el interés artístico de Mariluán, más allá o más acá de sus ambigüedades, reside precisamente en la provocadora fabulación del país que falta en el tiempo mismo del proyecto de sometimiento definitivo de uno de los pueblos que constituyen lo que llamamos Chile.

Mariluán puede leerse en más de un aspecto como una novela panóptica, regida por un narrador que deviene una marca de poder, alguien que vigila constantemente el mundo ficcionalizado, tal como lo hace el vigilante instalado en la torre central del panóptico inventado por Bentham. La vigilancia completa de los personajes y del espacio, cualidad que la crítica llama omnisciencia del narrador, hace visible una relación de tal modo intensa entre novela y poder que no parece exagerado definir la novela realista, específicamente la de aprendizaje, como un dispositivo disciplinario semejante a la prisión, la escuela, el regimiento o el manicomio, con la lógica diferencia que marca su carácter imaginario. Dispositivo textual, en todo caso, que nunca cumple la totalidad de sus designios, pues siempre quedan zonas oscuras que el narrador no logra o no puede iluminar. Son éstos los límites de la mirada panóptica, pero también los lugares de las fugas, de las líneas de resistencias al poder disciplinario que esa mirada reproduce en el espacio literario. Blest Gana crea un narrador que realiza una vigilancia completa de los personajes y de los espacios, pero lo fascinante es que tal aparato de control funciona realmente como contra-panóptico, como contra-mirada que erosiona profundamente el régimen de verdad hegemónico en la sociedad chilena de la época de la publicación de Mariluán: "(la pacificación definitiva de la Araucanía) es la causa del derecho, la causa noble y grande de la civilización contra la barbarie" (Saavedra 1870:30).

La luz etnófaga que ilumina la mirada del narrador de Mariluán proviene, sin duda, de la energía del sol incontrastable del "progreso y de la unificación nacional, que ésta es la ley universal que, aunque dura, rige y triunfa

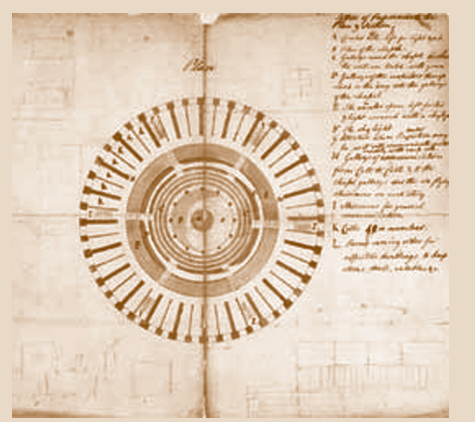

Esquema del panóptico de Bentham 
donde quiera que haya una agrupación más civilizada que las demás" (Lara 1889, I, pág. 14). La simiente misma de la "noble esperanza" del protagonista, por ejemplo, proviene de esa fuente de claridad: "El sol fecundo de la civilización había hecho germinar en el pecho de Mariluán la simiente de una noble esperanza: quería regenerar a su raza por medio del trabajo y de la honradez. A este elevado fin consagró sus pensamientos y su vida" (Blest Gana 1964, Cap. XX, pág. 241). También el dualismo estructurante de la diferenciación de los personajes y los espacios novelescos. El narrador fascinado por el mito de la irradiante luminosidad de la civilización reproduce aquí lo que parece ser la norma misma de la reinvención republicana del "bárbaro araucano" en la época de su "feliz conquista". Me refiero a lo advertido por Foresti en su análisis de relatos como "El amor de un indio" de Carlos Aldunate (1875), "La salvación por una flauta" de Valentín Trujillo (1876) y "La muerte de Lautaro. Tradición indiana" de Juan de Dios Vial (1870): "La representación narrativa de los indígenas en el relato decimonónico puede ser a veces positiva, pero nunca se aleja totalmente de la antinomia civilización-barbarie. El indígena 'bueno' suele tener las marcas explícitas de una occidentalización discursiva. Es necesario que el indígena que cumple papel protagónico en un relato se destaque con cualidades de acuerdo a la pauta de conducta 'civilizada', según el horizonte ideológico del emisor. En estos casos, la caracterización se hace a partir de la negación de la pauta de conducta de los demás de su tribu. De esta manera, en el mismo discurso se entrelaza un discurso anti-indígena que se refiere al colectivo, con otro pro-indígena que se refiere al individuo, digno de ser destacado por ser 'distinto a'..." (Foresti 2001, II, pág. 213). Los momentos de tal entrelazamiento son numerosos en la "novela olvidada" de Blest Gana. El contraste entre Mariluán, Caleu y Peuliquén, ya destacado por los críticos, es sólo el más ostentoso de ellos. La crónica de 1862 resiste, sin embargo, su reducción a dicho tropismo contradictorio, fundamentalmente porque en ella se produce lo impensable, lo inconcebible en el panóptico. Este dispositivo está hecho para mirar, no para ser mirado, para iluminar al otro, no para ser iluminado por él. El agente de esta escandalosa torsión del sentido del panóptico, del régimen de mirada predominante en la novela realista, es fundamentalmente el discurso del rebelde que hace un verdadero streap tease de la civilización chilena. La verdadera barbarie, dice Mariluán, no está en la sociedad araucana, por mucho que los personajes llamen a la Araucanía "madriguera de salvajes" o "tierras de salvajes". Está en un lugar inconcebible en los relatos de Saavedra o de Barros Arana, inimaginable en los relatos de los vecinos de Los Angeles o de Arauco: la sociedad chilena.

Narración panóptica cuyo vigilante está fascinado por la quimera del vigilado. Atraído, sin duda, pero también temeroso. Reescribo en este aspecto lo ya dicho en mi extenso estudio "La buena nueva" (Triviños 2001), no por narcisismo (tal vez sí) sino por necesidad de mi argumentación sobre el 
germen utópico que entonces no vislumbré en Mariluán. Se trata sobre todo de establecer ahora la "singularidad esencial" del texto cifrable en la definición de Piglia: la literatura es, en última instancia, una forma privada de la utopía. Tal especificidad, que permite comprender la mayoría de las llamadas contradicciones o ambigüedades del relato, no es otra que la forma realista de la elaboración de los deseos perturbadores. La novela realista, europea y americana, del siglo XIX, específicamente, se singulariza, en efecto, por la atracción y a la vez el rechazo de los deseos transgresores portados por las inquietantes figuras del revolucionario, del libertino, de la adúltera, del loco, del salvaje, del rebelde. El deseo es una amenaza para la forma realista. Subvierte el orden social y también el orden novelesco (Bersani 1982). El escritor realista siente, sin embargo, gran atracción por los héroes que encarnan el deseo destructor. Los reprime con una brutalidad que choca ( $E l$ audaz, La regenta, Fortunata y Jacinta, Cádiz, Madame Bovary), los somete a ceremoniales de expulsión como la muerte, la locura, la renuncia o la soledad, pero a un mismo tiempo multiplica los "momentos subversivos", los disemina sin cesar entre los personajes principales y secundarios. Madame Bovary, Julián Sorel, Ana Azores, Lord Gray, Fortunata, Juanito Santa Cruz, Fabricio del Dongo, Juan Santiuste, Acab, Nazarín, Luis de Santorcaz, Rafael San Luis, Mariluán, Rosa, Peuquilén... Los nombres de estas figuras fascinantes son innumerables. Las novelas por ellos protagonizadas, empero, exigen, para que sea posible su existencia misma, la aniquilación o, por lo menos, la paralización de sus tendencias anárquicas. El héroe, concluye por ello Bersani, es un intruso, un extraño en el mundo de la literatura realista. No, sin embargo, porque ese mundo sea el "verdadero", incompatible con el idealismo romántico, sino porque dicha incompatibilidad es una elección a priori del novelista cuyo héroe parece cifrar una empresa de subversión a la que él mismo ha ya renunciado (1982:66-67). Mariluán, texto escrito dentro de "las normas del gran realismo decimonónico" (Ballard, 1983:66-67), se inscribe dentro de esta lógica novelesca regida simultáneamente por la atracción y el miedo a los deseos socialmente perturbadores. El asesinato de Mariluán, la locura de Rosa y la muerte de Peuquilén son, en este caso, los rituales de muerte y locura que expulsa del discurso y de la historia al rebelde, a la chilena enamorada de un indio y al salvaje concupiscente. El héroe fascinante, por su parte, fracasa doblemente. No se une para siempre con Rosa Tudela ni logra la regeneración de su pueblo. No es rigurosamente exacto afirmar, en este sentido, que Blest Gana "se identifica con el protagonista consciente de que el mundo mapuche, para sobrevivir, debe necesariamente adaptarse a los requerimientos de la sociedad chilena, pues no es viable la existencia de un territorio autónomo, al interior del país" (Antillanca y Loncón 1997:93). Tal lectura, como aquélla según la cual la dicotomía sarmientina entre civilización y barbarie se resuelve idealmente en un proyecto de salvación por la cultura (Epple, en Antillanca y Loncón 1997:93), 
oscurecen, silencian o deforman los sentidos más provocadores de Mariluán como novela del aprendizaje del único modo de negociar con el fuerte. Significaciones que emanan, precisamente, del miedo y la atracción del novelista por el subversivo descubrimiento del militar desertor y rebelde. Me refiero a la "noble idea" (¿realista o romántica?) de Mariluán: imponer reparación y justicia mediante la fuerza, pues "con el fuerte se trata y al débil se le oprime": "(Los) indios no podrán obtener la reparación y la justicia si no se presentan fuertes y terribles (para) que se les devuelvan las tierras que se les han arrebatado por engaños y fraudes, que se les restituyan los prisioneros, que se reglamenten los contratos entre españoles y araucanos, dando a éstos las garantías de que carecen: en una palabra, que se les asegure el amparo de las leyes a que todo ciudadano chileno tiene derecho, y ellos ofrecerán por su parte las garantías que se les piden" (1964, Capítulo XIX: 233-234). La salvación por la cultura ("trabajo y honradez") no horroriza al novelista liberal. Le da miedo, como los ceremoniales de expulsión del "generoso descendiente de los héroes inmortalizados por la epopeya" (Capítulo XIX) lo testimonian, la rebelión portadora del deseo que el relato realista chileno no puede tolerar, aun cuando la fascinación por esta empresa "noble" y "santa" sea profundamente intensa. El tema de la salvación por la cultura no permite comprender el olvido de Mariluán. Lo explica la misma necesidad que lleva a los pacificadores de la Araucanía, empeñados en blanquearse a toda costa, a borrar las clarísimas estrofas que dan nacimiento a Chile: las páginas que legan a "nosotros, los indios" épica y humanismo: el poema-camino cuyo autor concede la categoría de héroes "a los españoles y a los indios, a los suyos y a los nuestros. Pero su corazón estuvo con los indomables" (Neruda 1978:272-274).

Atracción y temor por el deseo perturbador. Enfoque dual del otro. Ambigüedad moral y estética. Estos parecen ser los límites de Mariluán como viaje de un escritor chileno a la alteridad araucana en la época de la transfiguración del otro étnico en "raza estúpida, mengua y oprobio de la nación chilena". Límites, pero no anulaciones de su fundamento utópico. No tachamiento de las fugas narrativas de los mitemas constitutivos del "regimen de verdad" predominante en 1862 , cuando ya se ha iniciado el plan chileno de conquista definitiva de la Araucanía. Mariluán es y no es, por ejemplo, un relato de salvación por la cultura. Su fuerza transgresiva reside, en más de un aspecto, en los lugares que resisten la inscripción sin más en dicha modalidad narrativa. Ahí donde este panóptico al revés descubre la verdadera barbarie que mantiene eternamente separados a los chilenos y araucanos. Ahí donde el narrador hace mirar lo que no debe mirarse, pensar lo que no debe pensarse, descubrir lo que no debe descubrirse: la índole destructora del sol fecundo, su pulsión genocida:

-Nuestra causa (...) no ha menester de la traición para triunfar. Serán sus

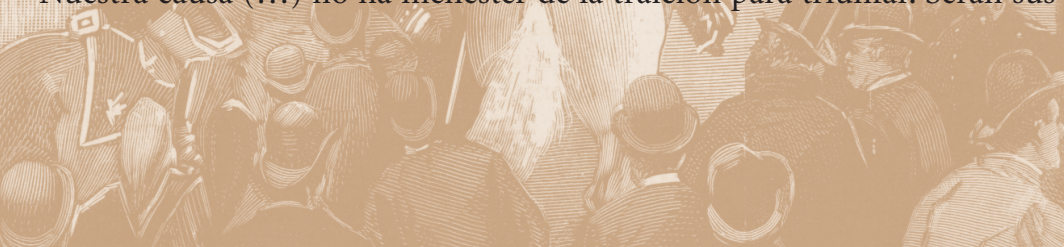


defensores los que van a pelear por sus hogares violados, por sus hijos arrebatados de los brazos de sus madres para venir a ser esclavos de los que se llaman civilizados ya que los regalan a un amigo como quien regala un animal. Tan justa causa no debe ser manchada por el que pretende como yo, ser su jefe. Los hombres de buena voluntad, que comprenden que esos indios son parte de la familia humana y tengan la energía de consagrar sus vidas a redimirlos de su largo infortunio, ésos, encontrarán un lugar en nuestras filas (1964, Capítulo III: 111).

Mariluán es y no es, asimismo, el relato de un puro fracaso. El héroe novelesco no logra, qué duda cabe, ninguno de sus dos sueños, ni el privado (libertar a Rosa Tudela de la opresión familiar) ni el público (libertar a los araucanos de la opresión de los chilenos). El texto no dice, sin embargo, que el proyecto emancipador de Mariluán es por ello una quimera irrealizable, un delirio que nadie imitará. Ni la antigua ni la nueva crítica de la novela han reparado, en este aspecto, en la importancia fundamental de la elaboración narrativa de la empresa del caudillo rebelde, particularmente de su muerte, como un sacrificio fecundo. Aquí, en estas dos palabras de los discursos del narrador y del protagonista, se cifra la gran fuga del mito civilizatorio del que Mariluán extrae, no obstante, sus dualismos, imágenes, figuras y metáforas. La derrota de los rebeldes evidencia el "poder incontrastable" de la civilización en la Araucanía , pero al mismo tiempo testimonia en Chile lo que María Zambrano, en el prólogo de La tumba de Antígona, llama la raíz misma de Occidente, la pasión que preside su historia: el sacrificio. No sólo eso. Mariluán, dispositivo disciplinario que no logra borrar las marcas de su fascinación por los deseos que debe expulsar, termina revelando lo también inconcebible en el panóptico al derecho: el retorno de lo que se quiere reprimir, la índole indestructibl de lo ilusoriamente disciplinado. El deseo intolerable que los textos coloniales llaman la "ruin imaginación" de la rebelión no se extingue, en efecto, con el fracaso de la rebelión araucana ni con la muerte del caudillo que la instiga. Ello porque el cronista de la insurrección logra vislumbrar, aunque de modo confuso y contradictorio, la regla misma del mundo dentro de la cual se inscribe el trágico fin del rebelde. No ya la "ley universal" del triunfo inevitable del progreso, legitimante de la reducción del otro "bárbaro" en el relato nacional chileno, sino la fatalidad también universal del Gran Juego.

Ballard señala brevemente en 1983 el diálogo de Mariluán con La Araucana, perceptible por lo demás de modo explícito mediante el recurso del libro dentro del libro, de la lectura transfiguradora dentro de la lectura: "En medio de su actividad y del escrupuloso cumplimiento de sus deberes, Mariluán encontraba siempre algunas horas para dedicarse a su lectura favorita. El poema de don Alonso de Ercilla despertaba en el alma de este indio, pulido por la civilización, ese orgullo que las razas perseguidas culti- 
van como una religión salvadora. El caluroso discurso de Lautaro, que hace tornar 'los generosos pechos' a los derrotados araucanos y cambiar en irresistible ataque la carrera de los fugitivos, hacía brillar en la vista de Mariluán los destellos que despiden los ojos de un hijo amante a quien refieren los hechos de un padre que la suerte no le permitió conocer. Rugía de coraje su altanero pecho con el atroz suplicio de Caupolicán, y cada fibra de su corazón respondía con rabia palpitante a la rabia desesperada de Fresia. Las alucinaciones del entusiasmo le hacían oír voces proféticas que le llamaban a continuar la gigantesca resistencia de sus antepasados y esas voces decidieron de su destino" (1964, Capítulo I: 100). Mariluán, dice el crítico mencionado, no sólo complementa La aritmética en el amor y Martín Rivas a través del desarrollo en clave realista de espacios físicos y humanos netamente nacionales, sino que, además, es una continuación de la tradición literaria establecida por La Araucana de Ercilla (Ballard 1983:71). Los estudios posteriores, especialmente los análisis de Barraza (2002) y Troncoso (2003), destacan aspectos relevantes de esta relación. Mariluán, no obstante, se vincula con La Araucana de un modo más perturbador que lo ya evidenciado. Me refiero, específicamente, a los devenires en estos textos, cuestión fundamental si recordamos que escribir es devenir otra cosa que escritor (Deleuze). La mayor fuerza transgresiva de uno y otro, razón secreta de su borradura en la nación que no es un país de indios, proviene, sin negar sus grandes diferencias, de la "lástima justa" de sus narradores y protagonistas por el sufrimiento de los vencidos. ¿Eso que podríamos llamar con escándalo el devenirindio del español y del chileno? Lo dicho por Neruda del libro que es un camino es extensible, en todo caso, a la novela que también es un camino para aprender a vivir, para vivir juntos en Chile: "Pero su corazón estuvo con los indomables". La ficcionalización de la muerte del caudillo araucano como sacrificio fecundo adquiere aquí la plenitud de su sentido provocador. Mariluán muere, pero su martirio no es estéril, porque cae hacia los que van a nacer, hacia sus dobles o espectros del presente y del porvenir, entre ellos, su hermano Cayo: “-Aun cuando muera sin realizar mis planes (...) no creo que mi sangre será estéril: ella fecundará una idea grande y yo habré cumplido con mi deber" (1964, Cap. XIX:235). La familia textual de Mariluán no es la serie prisionera del mito civilizatorio, de su sol fecundo, aun cuando en más de un aspecto es imposible desligarlo de él. Sus reales parientes son, por el contrario, los que erosionan profundamente la mitología legitimante de la pacificación definitiva de los hombres de la tierra. La Araucana, Quilapán, Canto general, Poema de Chile, Pasión y epopeya de Halcón Ligero, Memorial de la noche, Se ha despertado el ave de mi corazón. La familia que no borra la regla del mundo descubierta por el inventor de Chile en el suelo mismo de la Araucanía: la fatalidad del Gran Juego. Poder de la idea, poder de los hechos, dice Baudrillard en el siglo XX. Poder de la literatura, dicen Ercilla en el siglo XVI, Blest Gana en el siglo XIX, Lillo, Mistral, Neruda, Subercaseaux, 
Manns, Chihuailaf, Lienlaf, Harris en los siglos XX y XXI: "muertos podremos ser, mas no vencidos, / ni los ánimos libres oprimidos (...) Nómbrala tú, di conmigo / brava-gente-araucana. / Sigue diciendo cayeron. / Di más: volverán mañana (...) Más hondo caía esta sangre. Hacia las raíces caía. Hacia los muertos caía. Hacia los que iban a nacer (...). Lautaro viene a buscarme, I a buscar a su gente / para luchar con el espíritu / y el canto. /// Tu espíritu Lautaro / anda de pie / sobre esta tierra"... Parece enterrado el otro étnico en el Reino (Arauco domado) y la República de Chile (Pacificación definitiva de la Araucanía), pero desde la muerte renace, "para ser otra vez semilla / más numerosa en la tormenta", en la familia engendrada por "el maravilloso caballero, por el grandioso poeta, por el hidalgo don Alonso de Ercilla" (Neruda). El error de la lectura que se limita a analizar el fracaso del héroe, sin advertir la fecundidad de su sacrificio, es por ello grave. Silencia sin quererlo la significación más disolvente de la novela en el tiempo mismo del paroxismo violento que llamamos pacificación de la Araucanía. Borra, como corresponde entre los chilenos, la verdad ineluctable del Gran Juego: "De una parte, el Otro siempre está muerto; de la otra, es indestructible".

La novela que así subvierte el mito del "poder incontrastable" de la civilización sobre la barbarie representa espacios físicos y humanos nacionales según las normas del gran realismo del siglo XIX. Logra integrar, según Ballard, los elementos que la constituyen (económicos, sociales y políticos) de un modo más armónico, más logrado artísticamente, que en Martín Rivas y La aritmética en el amor. Su lectura produce, sin embargo, una extraña sensación de irrrealidad, de inverosimilitud. No me refiero sólo a la falta de descripciones pormenorizadas de los espacios chilenos y araucanos, ausencia ya destacada por los críticos, yo mismo entre ellos, sino fundamentalmente a las relaciones interétnicas, regidas por representaciones que Barraza, lector del autor de Escribir en el aire, llama imágenes armónicas y extemporáneas de lo que obviamente es desgajado y beligerante, "figuraciones que en el fondo a quienes conviene imaginar nuestras sociedades como tersos y nada conflictivos espacios de convivencia (Cornejo Polar)":

Mariluán, si bien evoca a los héroes de Ercilla, a quien lee, en el presente participa como un 'igual' en la sociedad civil y militar de entonces, que 'borra' o 'blanquea' su condición de mapuche cautivo entregado por su padre, en 1827, como prenda de paz en Tapigue. La sociedad dominadora lo ha 'beneficiado' con la educación y la civilización, al extremo que no se diferencia de cualquier otro chileno. Su condición de buen oficial, mejor bailarín y cantante en turtulias y esquinazos le permite recibir un trato igualitario en el ejército y en la sociedad chilena. Es correspondido por Rosa Tudela, quien pertenece a una distinguida familia de Los Angeles -en plena Araucanía sin que ella ni su madre reparen en su condición de mapuche. Mariano, hermano de Rosa, sólo se opone al noviazgo porque prefiere un pretendiente con 
mayor solvencia económica y no duda en batirse con él, como con cualquier otro hombre de honor (...) Juan Valero, oficial del ejército como Mariluán, no ve como afrenta que éste lo tome prisionero, no le reprocha su alzamiento y colabora en su huida. Mariluán resultaría, así, un chileno como cualquier otro a quien 'se puede estrechar las manos y con quien se puede conversar', en una sociedad que se precia de porosa y tolerante, no clasista ni segregacionista, que no discrimina frente a la diversidad étnica o económica de sus integrantes sino que los iguala o les permite el tránsito desde un estrato a otro, como lo ilustra, en ese mismo año, Martín Rivas (Barraza 2002:194195).

La novela, ha dicho Stevenson, es una obra de arte no tanto por sus semejanzas inevitables con la vida como por las diferencias inconmensurables que la separan de ella. Diferencias inconmensurables. Mariluán, donde el "mundo imaginario", más allá de todas las protestas que pudieran hacerse sobre su realismo artísticamente superior (Ballard), parece el doble invertido del "mundo real", es un testimonio ejemplar de dicha definición. Blest Gana no escribe, con todo, un idilio interétnico. Construye un relato trágico que parece terminar de modo ostentoso con el triunfo de las fuerzas destructoras de Thanatos sobre las fuerzas integradoras de Eros. Raúl Silva Castro tiene razón cuando destaca "el gran número de incidentes sangrientos, algunos sencillamente horripilantes" de Mariluán, pero se equivoca cuando afirma que muchas de las peripecias así narradas "nada tienen que ver con el desembarazado curso de la fábula". La novela cuyo autor "no estudió suficientemente el personaje, no meditó bastante la intriga (y) cedió al deseo de acumular efectos trágicos y sangrientos para producir en el lector impresiones de horror" (Silva Castro 1941:413) es, sin duda, un relato de muerte, pero se escribe pora negarla, para resistirla. La ficcionalización del fin trágico del protagonista como muerte fecunda, característica de la familia literaria a la que Mariluán pertenece, es la forma de fuga tal vez más creadora mediante las cuales el texto traza sus líneas de resistencia contra las potentes fuerzas de Thanatos. El conflicto trágico, dice María Zambrano, no alcanzaría a serlo si consistiera solamente en una destrucción de la que no se desprendiera algo que la sobrepasa y rescata (1989:201). Este es el caso de la novela sobrecargada de "efectos trágicos y sangrientos". La muerte fecunda del héroe que se sacrifica por amor a su pueblo y la fabulación del país liberado de la pasión del sacrificio constituyen precisamente la trascendencia propia del texto trágico, sus Euménides liberadoras. Delirio irrealizable, diría Raúl Silva Castro sobre la fabulación que convierte a Mariluán en otra cosa que el relato de una pura catástrofe, sin nada que la sobrepase. Delirio creador de una posibilidad de vida, replican el araucano y la griega. El héroe novelesco, afirman de un modo u otro sus nuevos lectores, es en definitiva un civilizado que conduce a los mapuches hacia un triunfo que es una mo- 
derna forma de muerte (la muerte cultural). Reléanme, responde la novela así (mal) leída: analicen detenidamente todos los discursos del protagonista. Reparen en la importancia de la oposición trágica entre la Ley Vieja ("antiguo y perpetuo origen de esta lucha eterna con los araucanos") y la Ley Nueva ("que se les mire como hermanos y no como a un pueblo enemigo"). Interpreten las formas de muerte fecunda que resisten el imperio ostentoso de Thanatos. Hagan visibles las fugas narrativas del mito sacrificial que terminan revelando lo inimaginable en el relato de un civilizador o un civilizado: la regla del Gran Juego, el lugar de la verdadera barbarie, la alteridad indestructible, el pueblo que falta: el país de Mariluán, que, asombrosamente, es el mismo país fabulado por Antígona, "la ciudad de los hermanos, la ciudad nueva, donde no habrá ni hijos ni padre. Y los hermanos vendrán a reunirse con nosotros. Nos olvidaremos allí de esta tierra donde siempre hay alguien que manda desde antes, sin saber. Allí acabaremos de nacer, nos dejarán nacer del todo. Yo siempre supe de esa tierra. No la soñé, estuve en ella, moraba en ella..." (Zambrano 1989:252).

Panóptico al revés. Mirada fascinada por el otro que debe mirar. Descubrimiento del lugar de la verdadera barbarie. Escritura de los devenires minoritarios de Mariluán y del narrador. Desplazamiento de la mirada que extrae su luz del sol fecundo de la civilización por una contra-mirada iluminada por la intolerable claridad del Gran Juego. Lugar del encuentro fascinante con el poema-camino del inventor de Chile. Fabulación del país que falta, sin "hijos ni padre". Novela de Blest Gana, en síntesis, que en última instancia es una forma privada de la utopía. No ignoro, por supuesto, el carácter problemático de esta definición de Mariluán después de la advertencia de Adolfo Bioy Casares ("Si urdes utopías recuerda que el sueño de uno es pesadilla de otro"), pero sobre después del lúcido Huairapamushcas. La búsqueda de la identidad en la novela indigenista hispanoamericana, libro de Braulio Muñoz cuyas conclusiones fundamentales pueden funcionar perfectamente para decir, por ejemplo, que la novela del escritor que no es araucano es una defensa del hombre de la tierra en cuyo mensaje yace la esperanza de su muerte cultural, el deseo de expulsar el espectro de Lautaro para lograr, por fin, el sueño de la unidad cultural chilena: "El Sueño y la utopía fueron importados. Aquellos que han debido sostenerlos, nunca fueron consultados. Hay fundadas razones para pensar que los indios no han deseado para nada una utopía, que desde el principio se basó en la exclusión y que promueve su desaparición. Al principio, perteneció al conquistador; después, al mestizo, en cuyo cuerpo el indio podría caber. Pero, la participación indirecta, casi de pasada, nunca es suficiente. La felicidad del mestizo nunca puede ser la del indio" (1985:31). ¿Mariluán es, entonces, la elaboración literaria de un sueño que a la vez es una pesadilla? La tentación de terminar este artículo con esta interrogante, posibilitada por los momentos narrativos regidos aparentemente por mitemas propios del relato civilizato-

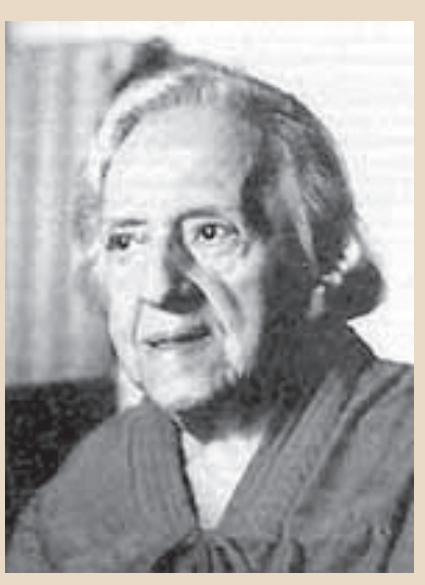

M. Zambrano 
rio de la salvación por la cultura ("quería regenerar a su raza por medio del trabajo y de la honradez"), es muy grande. El texto mismo de un devenir indio, empero, impide esta conclusión que finalmente disciplina el deseo en cuyo libre fluir reside precisamente su fuerza transgresiva. Me refiero, específicamente, a su fluir en la idea y en el hecho de la fatalidad del Gran Juego, a la línea del descubrimiento de la indestructibilidad del otro pueblo trazada por la familia textual fundada por La Araucana: "Muertos podremos ser, mas no vencidos (...) Vosotros, cristianos, habéis fracasado". El diálogo fascinante de Mariluán con La Araucana impide esta reducción. Hay secretos en esta novela, pero ellos son de naturaleza muy distinta. Se vislumbran, en todo caso, en el comienzo novelesco mismo: "este hijo de las selvas vírgenes llegó a transformarse en el elegante oficial de granaderos que vamos dando a conocer (...) Pero ni los beneficios de la educación, ni el roce con las gentes civilizadas que le enseñaban hábitos de cultura muy diversos a los contraídos en su niñez, pudieron jamás borrar del alma de Fermín Mariluán ese amor instintivo al suelo patrio, que en la raza araucana ha producido los altos hechos que celebra la epopeya (...) Mariluán veía renacer las escenas de la infancia, los poderosos recuerdos de la familia, acompañados de esa abrumadora melancolía que cierne sus alas de ángel doliente sobre el alma de los desterrados" (1964, Cap. I: 99). La novela que así resiste el esfuerzo disciplinatorio de sus críticos no consuma el crimen perfecto ejecutado en el mito de la salvación por la cultura. Revela exactamente lo contrario: la imperfección del exterminio de la alteridad. Es el secreto de La Araucana cifrable en las "voces proféticas" que transfiguran el destino del elegante lector indio del Capítulo I de Mariluán. El secreto del residuo. El origen de los puntos de caos: "Las sociedades occidentales redujeron la realidad del otro por colonización o por asimilación cultural; redujeron lo que había radicalmente heterogéneo e inconmensurable en el otro (...) Pero en esta gestión del prójimo queda un residuo; en el otro se esconde una alteridad ingobernable, amenazante, explosiva; aquello que ha sido embalsamado o normalizado puede despertar en cualquier momento. El retorno efectivo o la simple presencia de esta inquietante alteridad está en el origen de las singularidades, los accidentes, las catástrofes; esos puntos de caos hacen bifurcar la historia, cambian un destino individual o colectivo" (Guillaume, en Baudrillard y Guillaume 2000:16). Así ocurre, leemos en Figuras de la alteridad, con la pasión erótica que hace surgir cruelmente la otredad que separa a dos seres y les permite acercarse lo más posible a la frontera, al punto de imaginarse a veces cruzarla. Sucede asimismo, dicen la historia, la memoria oral y la literatura latinoamericana, con las rebeliones, insurrecciones o desórdenes indígenas que hacen surgir cruelmente la alteridad en el mundo colonial y republicano. Los planteamientos e interrogantes implícitos en Mariluán, novela de un devenir-indio que se inicia con el retorno de lo reprimido y finaliza con el sacrificio fecunda del portador de lo expulsado no son, en este 
sentido fundamental, “¿valdría la pena invertir tanto esfuerzo civilizador con tan inciertos resultados?, ¿constituye la integración de los araucanos un requisito esencial para afianzar el Estado-nación?" (Troncoso 2003:90). Son sobre todo las preguntas que surgen del descubrimiento de la fatalidad del Gran Juego, entre ellas, ¿es (im)posible conciliar la independencia del pueblo araucano con la civilización?, ¿cómo vivir juntos en Chile sin intentar destruir lo que los hechos y las ideas demuestran que es indestructible?, ¿es ya (im)posible la "reparación y justicia" en la Araucanía?, ¿cómo "desmontar los cimientos de la ira” en el país que no tolera la existencia de gente diferente?, ¿es quimérico todo sueño de terminar con la "lucha eterna" de chilenos y araucanos?

Antígona y Polinices inventan bellamente la otra ciudad en la tragedia de María Zambrano que simboliza la guerra civil en la arquetípica muerte recíproca de dos hermanos. Estremece descubrir la secreta analogía de Mariluán con La tumba de Antígona: "En ella no hay sacrificio, y el amor, hermana, no está cercado por la muerte”. Blest Gana publica esta novela en 1862, cuando la Araucanía está ya cercada por la muerte. Escribir Mariluán en los momentos mismos del inicio en Chile de una nueva hipertrofia de muerte es un acto estético, ético y político de gran significado. Empresa de salud, es decir, invención de una posibilidad de vida, aunque ya trágicamente inactual y anacrónica en la sociedad regida por el relato legitimador de la inminente orgía sacrificial llamada con eufemismos perversamente mistificadores (feliz conquista, pacificación, hermosa y decisiva conquista). Su destino no es distinto del de las otras voces disidentes de la época: "Las primeras voces proindigenistas que se estaban escuchando en Chile fueron acalladas. Entre (los 60), los 70 y 80 el ejército avanzó implacable” (Pinto 1998:104).

La relación entre poder, novela y utopía es, pues, inevitable cuando se inscribe a Mariluán de Blest Gana en la tradición del "sufrimiento justo" por el exterminio del hombre de la tierra iniciada por La Araucana de Ercilla ("su corazón estuvo con los indomables"). La muerte fecunda del héroe que muere cayendo como sus antepasados hacia los que van a nacer o hacia los que ya han nacido (Cayo) es una de estas formas de fuga de la pulsión etnófaga. Otra de ellas, igualmente inconcebible en el relato hegemónico del siglo XIX, igualmente intolerable en la nación que no quiere ser un país de indios (Decreto perfumado: "no señor, no somos un país de indios"), es el delirio del protagonista, su fabulación ya no reductible (en parte) a una pesadilla enmascarada de bello sueño. Hablo, específicamente, de la utopía de la novela como delirio creador de una posibilidad de vida, lo que constituye el objetivo último de la literatura (Deleuze), su fundamento mismo (Bloch, Piglia). Braulio Muñoz, el mismo sociólogo que hace visible en Huairapamushcas el envés letal de la utopía en la novela indigenista hispanoamericana, reconoce, por lo demás, que la imaginación utópica, no obstante los riesgos señalados, tiene aspectos positivos, pues "al orientar la mi- 
rada hacia el futuro (...) nos ha permitido distanciarnos del presente y apreciar con mayor certeza su naturaleza opresiva. A través del sueño utópico, una humanidad oprimida proyecta sus esperanzas hacia una vida mejor; su abandono podría significar el abandono de las esperanzas de un futuro mejor y el peligro de sucumbir ante el pesimismo más absoluto respecto de lo que viene por delante" (1985:31). El cholo peruano concluye, además, su provocador testimonio destacando que el deseo por la justicia y la felicidad, "lo medular del elemento utópico que ha estado siempre presente en el pensamiento político y social de Hispanoamérica y que se ha encendido de nuevo", forman una esperanza indisoluble (1985:225). Nada pareciera vincular la imaginación de Braulio Muñoz con la de Alberto Blest Gana hasta este encuentro en que cada uno parece devenir el intercesor del otro. Un detalle produce estas impensadas "bodas contra natura". Es el punctum del empleo de unas mismas palabras para cifrar sus propias fabulaciones del pueblo que falta: justicia y libertad. Su gran semejanza dentro de su gran diferencia no debiera sorprender, porque finalmente pertenecen a la misma tribu latinoamericana: la tribu de los intelectuales hispanoamericanos inventores a veces desgarrados de otro modo de relaciones interétnicas.

La protagonista de La tumba de Antígona recuerda también bellamente la necesidad de vigilar el sueño de la ciudad de los hermanos, porque "un sueño así consume y se consume si no se cuida. La vida está iluminada tan sólo por esos sueños como lámparas que alumbran desde adentro, que guían los pasos del hombre, siempre errante sobre la tierra" (Barcelona, Editorial Anthropos, 1986:258). Mariluán, su gemelo indio, vigila así, cuida así el sueño que lo consume. Escuchemos, por fin, las voces fabuladoras del pueblo que falta en el panóptico narrativo que deviene contra-panóptico. Mirada seducida por el flujo de un deseo que debiera reprimir: la imaginación de lo imposible. Fuga hacia "lo otro y lo distinto".

El poema de don Alonso de Ercilla despertaba en el alma de este indio, pulido por la civilización, ese orgullo que las razas perseguidas cultivan como una religión salvadora (...) Las alucinaciones del entusiasmo le hacían oír voces proféticas que le llamaban a continuar la gigantesca resistencia de sus antepasados y esas voces decidieron de su destino.

No era extraño, por consiguiente, que tan constante preocupación llegase a hacer trazar a Mariluán un plan que acariciaba en el fondo de su alma. Dar cohesión a las diseminadas tribus que pueblan el territorio araucano; fomentar la fraternidad, que sólo puede hallar su origen en la unión; alentar el espíritu de independencia, y aprovechar el valor indomable de los indígenas, enseñándoles los adelantos guerreros de la civilización, para alcanzar una victoria que pusiese a los araucanos en aptitud de ajustar un tratado ventajoso con el gobierno de Chile: he aquí el sueño de este joven, frívolo al parecer, y en apariencia, también dormido entre los blancos halagos de un amor tiernamente correspondido (1964, Cap. I:100). 
Antonio, arrebatado muy joven por los chilenos de los brazos de su familia, en una de esas frecuentes correrías hechas al territorio araucano por el ejército de la frontera, había servido desde entonces como corneta en el regimiento de Mariluán. Los rigores de la disciplina militar no habían bastado a destruir en el corazón de aquel indio el instinto de independencia trasmitido de generación en generación por los que pusieron a raya el valor de los conquistadores españoles. Ese instinto hizo concebir a Antonio Caleu un plan de deserción... (1964, Cap. II:104).

Después de desempeñar sus obligaciones militares, regresó a su casa absorto en reflexiones muy cercanas a la tristeza. Sus dos amores: el de Rosa, que despertaba los sentimientos tiernos de su corazón, y el de la independencia de su raza, que hacía resonar los nobles instintos y las esforzadas dotes de su alma, se combatían en su pecho..." (Cap. VI:133).

"Tenemos derecho de conservar nuestro territorio y el sagrado deber de combatir por la defensa de nuestras familias. Os ofrezco mi vida para esto (...) Si muero, mi hermano podrá continuar mi obra. El fin a que aspiro es el siguiente: que el Gobierno de Chile reglamente la internación de sus súbditos en el territorio de nuestros padres; que las autoridades nos presten su amparo, comprometiéndonos nosotros a respetarlas; que nuestros hermanos sean devueltos a sus hogares, y que se nombren tribunales que oigan los reclamos que tenéis que hacer contra los que os han despojado de vuestras tierras" (1964, Cap. VIII:154).

Uníase (...) el presente al pasado en el espíritu de Mariluán, que saludaba con alma reverente a las divinidades de los primeros años, juraba con orgullo la emancipación, por medio de la libertad y del trabajo civilizador, de la raza cuya sangre circulaba por sus venas...(1964, Cap. IX:159).

-Seré pasado por las armas; pero no pasaré por la deshonra de faltar a mi conciencia -exclamó Mariluán con el acento de una orgullosa convicción.

-No te creía tan porfiado, Mariluán -dijo el alférez con acento de triste reconvención.

-Ni tan loco te creía yo -añadió su compañero-. ¡Sacrificarse por los indios!

-¡Uds. Olvidan que soy indio también! -replicó Mariluán con viveza.

-¡Indio civilizado y que vale más que muchos chilenos! -dijo el compañero del alférez.

- ¿Y por qué los demás de mi raza no han de poder civilizarse como yo? -repuso Mariluán.

Valero y su amigo bajaron la vista. Los ojos de Mariluán brillaban con un fuego extraño. Hubiérasele creído inspirado.

-Uds. no me han comprendido ni me comprenden -prosiguió-. ¿Creen acaso que poniéndome a la cabeza de los araucanos he tenido la loca pretensión de conquistar a Chile? Uds. conocen mi corazón; ¿se figuran que encendí la guerra para ver matarse a hermanos con hermanos? Y, sin embargo, la explicación de mi conducta es muy sencilla. Soy araucano, y no puedo mirar indiferente lo que sufren los araucanos: poner fin a esos sufrimientos, colocando a los indios en situación de hacerse oír del Gobierno, he aquí mi am- 
bición. Mas no podrán obtener la reparación y la justicia que merecen si no se presentan fuertes y terribles. Con el fuerte se trata y al débil se le oprime. Yo he querido salvarlos de esa opresión y que se les mire como a hermanos y no como a un pueblo enemigo del cual se pueden sacar esclavos, despojándole de sus tierras. A este fin he consagrado mi vida y por esa idea moriré: la creo noble, la creo santa. ¿No hemos peleado ya bastante por el triunfo de tal o cual mandatario? ¡Pues bien, yo quiero pelear por la felicidad de los que son mis hermanos! (1964, Cap. XIX: 233).

-Qué importan los peligros -exclamó Mariluán-: la vida del hombre, a mi juicio, vale más sacrificándose a una idea generosa y grande, que reservándose para llegar a la muerte después de una serie de días estériles y de satisfacciones egoístas. Yo nací araucano y es justo que me consagre al engrandecimiento de mi raza. Los que han asombrado al mundo con su valor son susceptibles de engrandecerse y concurrir a la felicidad del país en general. Este convencimiento ha dirigido siempre mis reflexiones y dirigirá mi brazo en el combate: que triunfe o que fracase, nadie me impondrá la idea de que un pueblo tan noble para defender su independencia es sólo una raza de salvajes incapaces de perfeccionamiento moral (1964, Cap. XIX: 234-235).

Tal es el trágico fin que ha conservado la crónica del generoso descendiente de los héroes inmortalizados por la epopeya. El sol fecundo de la civilización había hecho germinar en el pecho de Mariluán la simiente de una noble esperanza: quería regenerar a su raza por medio del trabajo y de la honradez. A este elevado fin consagró sus pensamientos y su vida. Su fe sincera en la justicia de su causa la hallaba en la convicción que le asistía de que el pueblo que posee tan incontrastable amor a la independencia y a la libertad, no podía dejar de poseer también dotes intelectuales relevantes y fáciles de cultivar.

En medio de los vicios adquiridos por los araucanos en una lucha de más de tres siglos contra enemigos que siempre enarbolaban la bandera de la opresión y del despojo, Mariluán divisaba a la raza primitiva de sus mayores, rindiendo a la muerte los heroicos pechos antes que doblar el cuello a la esclavitud que les amenazaba. Esta reflexión madurada por el estudio y el amor a las grandes acciones, hizo revivir en sus venas la sangre de Lautaro, y en su pecho nacer el entusiasmo por la fraternidad con los antiguos enemigos, después de conquistar la igualdad de derechos para sus hermanos" (1964, Cap. XX: 241).

El escándalo de la revelación es, pues, múltiple en la novela del perturbador retorno de la alteridad indestructible. Primer escándalo: El devenir-indio del elegante granadero del ejército chileno. Segundo escándalo: La Araucana es un libro peligroso en la sociedad disciplinaria chilena del siglo XIX: inocula el deseo de la "ruin imaginación" de la resistencia al orden republicano chileno. Tercer escándalo: Narración, en el comienzo mismo de la novela, de dos historias de fracaso de la domesticación del "bárbaro" Mariluán y Antonio Caleu. Este punto de caos destruye la mayor ilusión del poder civilizatorio: el crimen perfecto. La irrupción perturbadora del residuo delata su imper- 
fección: los beneficios de la civilización jamás borran en el alma de Mariluán el "amor instintivo al suelo patrio". Cuarto escándalo: El sufrimiento justo por el sufrimiento injusto del pueblo araucano. Quinto escándalo: La traición del narrador, "ojo del poder" en la novela de aprendizaje realista, a las normas panópticas. No se identifica con el deseo de despojo de los chilenos sino con el "sagrado deber" de resistencia de los araucanos. Clausura de la lógica narrativa misma del texto realista que reproduce la pulsión normalizadora de la sociedad disciplinaria. Sexto escándalo: Los dos amores del héroe: la chilena Rosa Tudela (transgresión de la norma étnica) y la independencia y civilización del pueblo araucano (transgresión del orden civilizatorio). Séptimo escándalo: La "noble aspiración" de conquistar mediante la guerra, porque con el fuerte se trata y al débil se le oprime, el derecho de los araucanos a conservar su territorio. La verdadera barbarie, dice Mariluán, está en "las violencias cometidas contra los araucanos por los habitantes de la frontera", entre ellas, las calumnias por viles intereses. Octavo escándalo: La consagración del héroe a la causa que cree santa: la independencia y civilización del pueblo araucano. Noveno escándalo: La aculturación es un instrumento de resistencia en el plan del desertor rebelde: "(les enseñará) los adelantos guerreros de la civilización para alcanzar (la) victoria”. Décimo escándalo: La fuerza fecundante del sacrificio heroico. El héroe que muere cae hacia los que van a nacer: poder de los hechos, poder de la idea: la alteridad radical es indestructible: clausura de la verdad de las novelas de aprendizaje que concluyen con el triunfo del disciplinamiento de los deseos perturbadores (Periquillo Sarniento).

El poder crítico más intolerable de esta "crónica contemporánea" se cifra, con todo, en los efectos de espejo invertido que ella produce en los lectores. Esa sensación, ya señalada, de estar leyendo una novela separada de la vida por diferencias inconmensurables. No cualquier figura de escisión, sino de cesura radical. Son las contra-imágenes engendradas por el delirio del protagonista. El rebelde no ignora esta distancia inconmensurable. Enciende la guerra en Chile precisamente con la finalidad tremenda de (empezar a) salvar el abismo entre la Ley Vieja del pasado y del presente (triunfo de Thanatos) y la Ley Nueva del futuro (triunfo de Eros). Es la gran diferencia con Antígona, su doble griega abandonada por todos los hombres y todos los dioses. Los une, por el contrario, la pasión por una idea sublime: la invención de la tierra no cercada por la muerte, no devastada por el sacrificio. Este es el escándalo realmente irreductible de la novela que, lejos de cortar el inquietante flujo del deseo rebelde de Mariluán, como sucede con la represión del deseo concupiscente de Peuliquén, lo libera para penetrar el límite de lo irreal y lo imposible. La epopeya fundadora de la familia de Mariluán inicia esta invención en el siglo XVI pero de manera cifrada, larvada. Dice tan sólo que "(la) mucha sangre derramada ha sido / (si mi juicio y parecer no yerra) / la que de todo en todo ha destruido / el esperado fruto de esta 


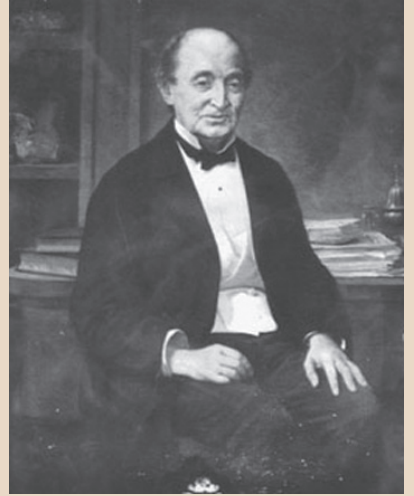

I. Domeyko tierra” (Ercilla 1962, XXXII:419). ¿Cuál es el esperado fruto de la tierra de Chile así destruido? Mariluán, "si mi juicio y parecer no yerra", responde provocadoramente tres siglos después, durante otra danza de la muerte, a esta interrogante implícita en La Araucana. El fruto esperado, todavía futuro, todavía sueño en el siglo XXI, es el país de dos pueblos hermanos, sin opresión de uno sobre otro, igualmente soberanos. Mariluán es, con todas las contradicciones detectables, uno de los nombres de lo imposible que impone su realización: "la fraternidad con los antiguos enemigos, después de conquistar la igualdad de derechos para sus hermanos". Sueño que debe cuidarse, porque un sueño así consume y se consume si no se cuida. Delirio que, como el de Antígona, es "presencia inviolable; una conciencia intangible, una voz que surge una y otra vez. Mientras la historia que devoró a la muchacha Antígona (y al indio Mariluán) prosiga, esa historia que pide sacrificio, Antígona (y Mariluán) seguirá(n) delirando" (Zambrano 1989:220221).

Voz que surge una y otra vez: Alberto Blest Gana edita Mariluán en 1862. Dos años después Francisco Bilbao, el revolucionario errante sobre la Tierra, publica El evangelio americano. Las diferencias de estos dos textos parecen inconmensurables, pero algo inquietante los vincula, algo los relaciona. Es su anacronismo, su inactualidad, en el tiempo (que aún es nuestro tiempo) de la negación hiperbólica del otro étnico en Chile. La invención de los pueblos que faltan: la buena nueva: "El libre pensamiento en América ha sido sostenido por las razas indígenas libres que combatieron y combaten; he ahí su tradición. (Arauco) recibirá la buena nueva de la fraternidad apoyada en el respeto de la autonomía de las razas" (1988:153). No sólo eso. El proscripto que ha descubierto, como Mariluán, que el verdadero enemigo interno de Chile en las relaciones interétnicas es "el desconocimiento y negación del derecho en los hombres libres, llamados los indígenas; y la suprema injusticia, la crueldad hasta la exterminación que con ellos se practica (1988:170-171), siente una gran fascinación por La Araucana. El 16 de enero de 1862, en el mismo año de la publicación de Mariluán, escribe a los hermanos Amunátegui (Miguel Luis y Gregorio Víctor) para tentarlos con una empresa que considera grande, útil, bella y fecunda: la edición de $L a$ Araucana: Díganme, amigos, ¿no se tentarían ustedes a hacer una edición de La Araucana, ilustrada y con notas? Para Chile es la Ilíada, allí la genealogía es nuestra Germania. Con los trabajos de Domeyko, Gay y otros viajeros, algunas vistas de paisajes y costumbres, con la etimología de las palabras aucas, con el desarrollo de la idea justísima que ustedes exponen en su libro, como fundador Ercilla de un ciclo literario, en fin, con una introducción como ustedes sabrían hacerla, y notas, sería el libro que el gobierno debía imprimir a cien mil ejemplares, en Europa. Sería una empresa grande, útil, bella y fecunda. Medítenla, mis amigos. Si Chile debe ser una nacionalidad, o algo sui generis, ha de apoyarse en Ercilla" (1988, XXVII. Las "voces 
proféticas" que inoculan el deseo perturbador del protagonista de Mariluán, novela olvidada de Blest Gana, son, pues, las mismas que iluminan la fulgurante invención del pueblo que falta en la obra de Bilbao, el pensador olvidado de Chile: las voces de La Araucana, el poema-camino cuyas "clarísimas páginas" son borradas por los mismos chilenos que la declaran su epopeya nacional.

¿Y cómo cortar el vértigo de este encuentro de Ercilla $y$ Blest Gana $y$ Bilbao si Neruda $y$ Mistral $y$ Subercaseaux $y$ Manns $y$ Lienlaf $y$ Chihuailaf $y$ Harris, por ejemplo, piden ser invitados a él? ¿Hay un secreto de La Araucana que pasa de uno a otro de tal modo que, más allá de sus diferencias, pertenecen a la misma tradición de escritores chilenos cuyo corazón está con los indomables. ¿Existe ese secreto realmente o yo soy sólo un aventurero que se mueve entre los textos buscando un secreto que no existe? Tal vez, en todo caso, la historia de la literatura chilena no es más que la historia de las múltiples variaciones del secreto que tal vez no hay, del retorno obstinado de la misma interrogación cifrada en La Araucana. El enigma sobre el esperado fruto que en Mariluán pareciera que no lo es por su alucinante claridad: "fraternidad con los antiguos enemigos, después de conquistar la igualdad de derechos para sus hermanos". Ese secreto que Baudrillard, (pen)último invitado a esta fiesta de invención de lo que todavía no es, nos permite definir como lo que queda después del (fracaso del) crimen perfecto:

La actual esclavitud de lo mismo y de la semejanza se romperá un día con la reaparición violenta de la alteridad. Soñábamos con pasar al otro lado de los espejos, pero son los pueblos de los mismos espejos los que irrumpirán en nuestro mundo. Y “esta vez no serán vencidos”.

¿Qué ocurrirá con esa victoria? Nadie lo sabe. ¿Una nueva existencia de dos pueblos igualmente soberanos, absolutamente extraños pero absolutamente cómplices el uno del otro? Nadie que ver en todo caso con la sujeción y negativa actuales (1997:201-202).

Lo que queda después de la orgía sacrificial de la modernidad es, pues, la memoria de su fracaso. La tradición de los que resisten cayendo hacia los que van a nacer. Los pueblos de los espejos que sutil o violentamente privados de su singularidad plantean ahora al orden social, político y biológico un problema irresoluble (Baudrillard 1997). Los fantasmas de los muertos que impiden el olvido de la regla del mundo. Los recuerdos del futuro: la quimera de Mariluán, el doble de Antígona que fabula el país no cercado por el sacrificio ( $¿$ "la nueva existencia de dos pueblos igualmente soberanos, absolutamente extraños pero absolutamente cómplices el uno del otro"?). Sueño que, como la vida imaginaria del indio civilizado Fermín Mariluán, y la real del indio civilizado Elicura Chihuailaf lo testimonian, impone su realización, porque "el hombre que vive y no Sueña es un hom-

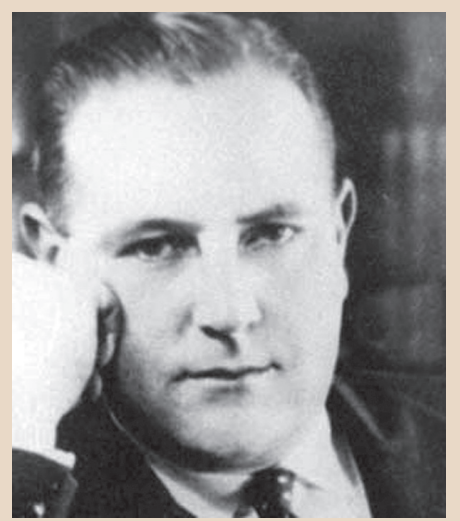

B. Subercaseaux

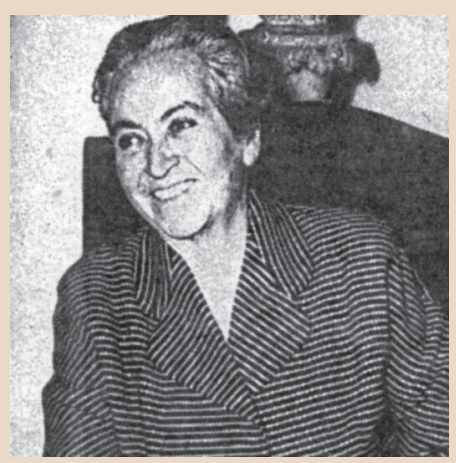

G. Mistral 


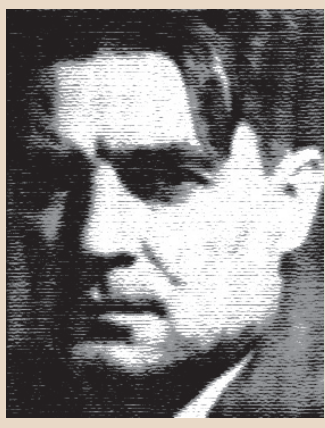

R. Arlt

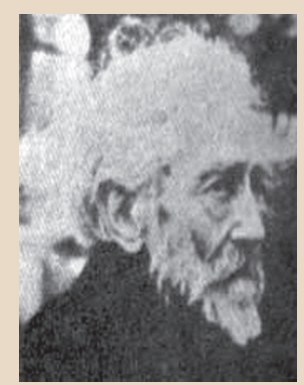

M. Fernández

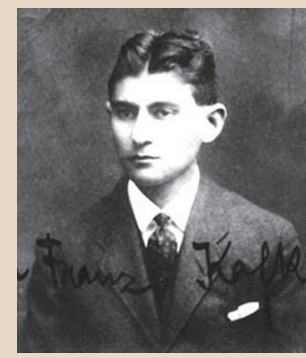

F. Kafka bre muerto en vida. Mas ¡ay! de aquel que Sueña y no realiza sus Sueños" (Chihuailaf 1999:38).

Queda, por último, el proyecto de continuar reflexionando sobre la novela realista, específicamente la de aprendizaje, como dispositivo disciplinario equivalente, en el ámbito literario, a la prisión, el manicomio, el regimiento o la escuela. Me parece que, independientemente de la sugerente teoría de las fugas novelescas del poder panóptico, hay que destacar, antes que nada, la diferencia radical que separa al vigilante central, tal cual es imaginado por Bentham, del narrador omnisciente de la novela realista. Esta figura omnicontemplativa del ojo del poder narrativo tiene, en efecto, unas características inconcebibles en el aparato panóptico. Está atraída por los deseos perturbadores y a la vez les teme. Los reprime, pero está fascinado por ellos. Esta es la norma, dice Bersani, no la excepción. Mariluán, específicamente, sugiere un panóptico por la "presencia universal y constante del gobernador del establecimiento", pero escandalosamente al revés, porque en vez de disciplinar los deseos "nocivos" del protagonista los libera. Los ceremoniales finales de exclusión de lo perturbador no logran silenciar el secreto de su fascinación. Tal vez hay dos grandes clases de relatos realistas: al derecho y al revés. La singularidad de los primeros sería, en este aspecto, el ocultamiento de la fascinación. El des-cubrimiento de la atracción, el signo distintivo de los segundos. Acaso podría establecerse, poniendo en relación los mismos textos señalados, otra clasificación. Aquella que distingue entre novelas cuyos ceremoniales de expulsión sugieren el triunfo del mecanismo disciplinatorio y novelas que revelan el carácter ilusorio, falaz, de esa victoria. Periquillo Sarniento o la domesticación del pícaro: mentira panóptica. Mariluán o la muerte fecunda del rebelde: verdad novelesca. Las narraciones realistas artísticamente superiores serían, entonces, las que descubren la "regla del mundo" ocultada en la "utopía programa" llamada panóptico: la verdad de la indestructibilidad del deseo. Poder de los hechos, poder de la idea que podría definirse así: "De una parte, el deseo perturbador está siempre reprimido; de la otra, es indestructible". Aquello que une al panóptico y a la novela es, paradójicamente, su radical incompatibilidad. El panóptico tiene por objeto la reproducción de lo existente. Trabaja para reprimir lo otro, mira incesantemente para que el portador de lo otro temido "pierda en efecto el poder de hacer mal, y casi el pensamiento de intentarlo" (Bentham 1979:37). La literatura, que en última instancia es una forma privada de la utopía en la que, sin duda, se inscribe la novela realista, "se instala siempre (por el contrario) en el futuro, trabaja con lo que todavía no es. Construye lo nuevo con los restos de presente. 'La literatura es una fiesta y un laboratorio de lo posible', decía Ernest Bloch. La novela de Arlt, como las de Macedonio Fernández, como las de Kafka o la de Thomas Bernhard son máquinas utópicas, negativas y crueles que trabajan la esperanza"(Piglia 1993:209. Una fiesta y un laboratorio de lo (im)posible. Máquina utópica 
que trabaja con la esperanza, es decir, la novela de Blest Gana donde el libre flujo del deseo de rebelión, la muerte fecunda del héroe, la fascinación del narrador por la causa "noble" y "santa" del desertor y la invención del país que falta cifran narrativamente, en el ámbito literario, la negación misma de los principios constitutivos del panóptico, el fracaso ostentoso de la finalidad misma de toda política de orden prisionera de la ilusión panóptica: "priva(r) a ciertos individuos de la libertad de que han abusado, con el fin de prevenir nuevos delitos, y contener a los otros con el terror del ejemplo" (Bentham 1979:35).

Mientras la historia que devoró a Antígona prosiga, dice María Zambrano, Antígona seguirá delirando. También el oficial desertor que se sacrifica porque no puede mirar indiferente el martirio de sus hermanos araucanos. Mariluán continuará delirando mientras prosiga la "lucha eterna" entre chilenos y araucanos. Su fabulación, que penetra los límites de lo irreal y lo imposible, descifra bellamente el enigma de La Araucana. El secreto de "lo otro" y "lo distinto" es la dolorosa creación de dos pueblos hermanos donde no hay sacrificio y el amor no está cercado por la muerte. Mariluán es el nombre del "objetivo último de la literatura: poner de manifiesto en el delirio esta "creación de una salud, o esta invención de un pueblo, es decir, una posibilidad de vida" (Deleuze 1996:16). El esperado fruto de esta tierra: aprender, por fin, a vivir juntos: aprender, por fin, a vivir de otra manera. "Y mejor. No mejor: más justamente. Pero con ellos": pertenecer a esa muchedumbre en la que uno va sin perderse, el Pueblo, andando al mismo paso con los vivos y con los muertos, pues ninguna ética, ninguna política y ninguna justicia parecen posible o pensable sin un principio de responsabilidad por esos otros que no son ya (Derrida): saber, por fin, que "nada de lo que creíamos superado, en la marcha irresistible hacia el progreso universal, nada de eso ha muerto, que todo resurge, no como vestigio arcaico o nostálgico (pese a nuestro prodigioso trabajo de museificación), sino con una vehemencia y una virulencia absolutamente modernas en el corazón de nuestros sistemas ultrasofisticados y ultravulnerables, estropeándolo sin esfuerzo alguno (Baudrillard 1993:148): descubrir, por fin, que el pueblo mapuche es lo que nos permite a nosotros, los chilenos, no repetirnos hasta el infinito. El huésped cuya vida es más preciosa que la nuestra (Gusinde: “¿qué se han hecho los onas? ...¡Perecieron!... ¡Están anonadados!”), porque “en este universo simbólico nada está en posición de alteridad diferente. Ni los animales, ni los dioses, ni los pueblos de los espejos, ni los muertos son otros. Los absorbe el mismo ciclo. Fuera de ahí, ni siquiera existimos" (Baudrillard 1993:152).

El autor de La transparencia del mal afirma que el artista está cerca del crimen perfecto, que es no decir nada. Blest Gana, fabulador del país que falta en el tiempo mismo de la pasión sacrificial que rige la historia de Chile, está cerca del crimen perfecto, pero se aparta de él. La novela de la fabula-

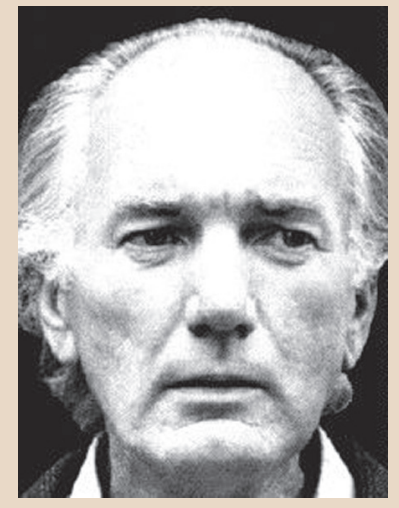

T. Bernhard

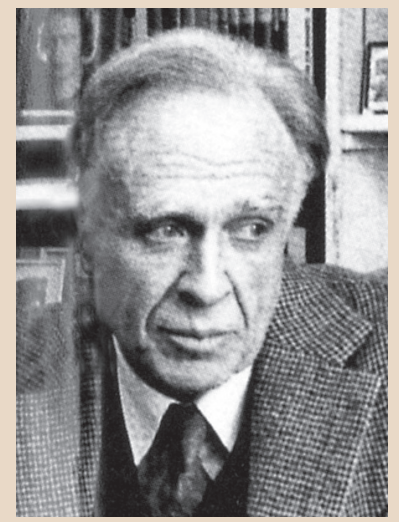

A. Bioy Casares 
ción de la ley nueva que reduce a cenizas la vieja ley multiplica las huellas de su imperfección criminal: los rastros del delirio del hermano indio de Antígona: "la fraternidad con los antiguos enemigos...". No podemos dejar de oírlo porque su delirio es nuestra propia conciencia oscurecida. Mariluán está enterrado vivo en nosotros, en cada uno de nosotros: "(En la tierra nunca vista por nadie) no hay sacrificio, y el amor, hermana, no está cercado por la muerte".

\section{Bibliografía}

Antillanca, Ariel y César Loncón. 1997. Entre el mito y la realidad. El pueblo mapuche en la literatura chilena. Santiago de Chile: Asociación mapuche Xawun Ruka, Editorial Lom.

Ballard, John Steven. 1983. "El ciclo de novelas socio-críticas de Alberto Blest Gana: el desarrollo de la estética realista y la ideología liberal”. Disertation. The Ohio State University.

Barraza, Eduardo. 2002. De la escritura de rebeldes a la rebelión de la escritura (El discurso de la conquista en la literatura chilena). Tesis de Doctorado. Universidad Austral de Chile, Facultad de Filosofía y Humanidades.

Baudrillard, Jean. 1993. La transparencia del mal. Barcelona: Editorial Anagrama. . 1997. El crimen perfecto. Barcelona: Editorial Anagrama.

Baudrillard, Jean y Marc Guillaume. 2000. Figuras de la alteridad. México: Taurus, La Huella del Otro.

Bentham, Jeremías. 1979. El panóptico. Madrid: Las Ediciones de la Piqueta.

Bersani, Leo. 1982. "Le réalisme et la peur du désir". En Roland Barthes et alii, Littérature et réalité. Paris: Editions du Seuil, pp. 47-80.

Bilbao, Francisco. 1866. "Los araucanos". En Obras completas de Francisco Bilbao. Edición hecha por Manuel Bilbao. Buenos Aires: Imprenta de Buenos Aires, pp. 305-350. . 1988. El evangelio americano. Venezuela: Biblioteca Ayacucho.

Blest Gana, Alberto. 1964. Un drama en el campo. La venganza. Mariluán. Santiago de Chile: Editorial Zig-Zag.

Casanueva, Fernando. 1998. "Indios malos en tierras buenas. Visión y concepción del mapuche según las elites chilenas del siglo XIX”. En Jorge Pinto (Ed.), Modernización, inmigración y mundo indígena. Chile y la Araucanía en el siglo XIX, Temuco: Ediciones Universidad de la Frontera, pp. 55-132.

Concha, Jaime. 1997. "Gramáticas y códigos: Bello y su gestión superestructural en Chile”. En Mapocho No 42, Segundo Semestre, pp.17-36.

Chihuailaf, Elicura. 1999. Recado confidencial a los chilenos. Santiago de Chile: Editorial Lom.

Deleuze, Gilles. 1996. Crítica y clínica. Barcelona: Editorial Anagrama.

Domeyko, Ignacio. 1971. Araucanía y sus habitantes. Buenos Aires-Santiago de Chile: Editorial Francisco de Aguirre.

Ercilla, Alonso de. 1962. La Araucana. Barcelona: Editorial Iberia. 
Foresti, Carlos, Eva Löfquist y Alvaro Foresti. 2001. La narrativa chilena. Desde la Independencia hasta la Guerra del Pacífico, Tomo II, Santiago de Chile: Editorial Andrés Bello.

Foucault, Michel. 1979. “El ojo del poder”. En Jeremías Bentham, El panóptico, Madrid: Ediciones de La Piqueta, pp. 9-26.

Gusinde, Martín. 2003. Expedición a la Tierra del Fuego. Santiago de Chile: Editorial Universitaria.

Lara, Horacio. 1889. Crónica de la Araucanía. Descubrimiento i conquista. Pacificación definitiva i campaña de Villarrica (Leyenda heroica de tres siglos). Santiago de Chile: Imprenta de "El Progreso".

Larraín, Jorge. Identidad chilena. 2001. Santiago de Chile: Editorial Lom.

Levinas, Emmanuel. 1993. Entre nosotros. Ensayos para pensar en otro. Valencia: PreTextos.

Muñoz, Braulio. 1985. Huairapamushcas La búsqueda de identidad en la novela indigenista hispanoamericana. Temuco: Ediciones Universidad de la Frontera.

Neruda, Pablo. 1978. "Nosotros, los indios". En Para nacer he nacido, Barcelona: Editorial Seix Barral, 272-274.

Neusüss, Arnhelm et alii. 1971. Utopía. Barcelona: Barral Editores.

Piglia, Ricardo. 1993. Crítica y ficción. Buenos Aires: Ediciones Siglo XX.

Pinto Rodríguez, Jorge. 1998. "Del antiindigenismo al proindigenismo en Chile en el siglo XIX”. En Jorge Pinto (Ed.), Del discurso colonial al proindigenismo (Ensayos de historia latinoamericana). Temuco: Ediciones Universidad de la Frontera, pp. 85-118.

. 2001. "La crisis del 900 y la literatura de la época. 18801930. Un análisis desde la historia”. En Varios, Chile, 1890-1930. Literatura e historia social, Temuco: Universidad Metroplitana de Ciencias de la Educación, pp. 79-138.

Román-Lagunas, Jorge. 1980. "Bibliografía anotada de y sobre Alberto Blest Gana". En Revista Iberoamericana No 112-113, julio-diciembre 1980, pp. 605-647.

Saavedra, Cornelio. 1870. Documentos relativos a la ocupación de Arauco. Santiago de Chile: Imprenta de la Libertad.

Silva Castro, Raúl. 1941. Alberto Blest Gana (1830-1920). Santiago de Chile: Imprenta Universitaria.

Triviños, Gilberto. 2001. "La buena nueva”. En Varios, Chile, 1880-1930 Literatura e historia social. Santiago de Chile: Universidad Metropolitana de Ciencias de la Educación.

Troncoso, Ximena. 2003. El espejo empañado. Literatura, nación y pueblo mapuche. Tesis de Doctorado. Concepción, Universidad de Concepción, Facultad de Humanidades y Arte, Programa de Doctorado en Literatura Latinoamericana. 270 pp.

Valenzuela, Víctor M. 1971. Chilean Society as Seen Through The Novelistic World of Alberto Blest Gana. Santiago de Chile: Talleres de Arancibia Hnos.

Zambrano, María. 1989. La tumba de Antígona. En Senderos, Barcelona: Editorial Anthropos, pp. 201-265.

. 1996. "Delirio de Antígona” y “Delirio, esperanza y acción”. En La Cuba secreta y otros ensayos. Madrid: Ediciones Endimión, pp. 98-105 y 164-170.

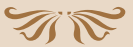

